\title{
Performance and long-term stability of the barley hordothionin gene in multiple transgenic apple lines
}

\author{
Frans A. Krens • Jan G. Schaart • \\ Remmelt Groenwold • A. Evert J. Walraven • \\ Thamara Hesselink • Jac T. N. M. Thissen
}

Received: 15 November 2010/ Accepted: 5 January 2011/Published online: 19 January 2011

(C) The Author(s) 2011. This article is published with open access at Springerlink.com

\begin{abstract}
Introduction of sustainable scab resistance in elite apple cultivars is of high importance for apple cultivation when aiming at reducing the use of chemical crop protectants. Genetic modification (GM) allows the rapid introduction of resistance genes directly into high quality apple cultivars. Resistance genes can be derived from apple itself but genetic modification also opens up the possibility to use other, non-host resistance genes. A prerequisite for application is the long-term performance and stability of the gene annex trait in the field. For this study, we produced and selected a series of transgenic apple lines of two cultivars, i.e. 'Elstar' and 'Gala' in which the barley hordothionin gene (hth) was introduced. After multiplication, the GM hth-lines, non-GM susceptible and resistant controls and GM
\end{abstract}

Electronic supplementary material The online version of this article (doi:10.1007/s11248-011-9484-z) contains supplementary material, which is available to authorized users.

F. A. Krens $(\varangle)$ · J. G. Schaart · R. Groenwold ·

A. E. J. Walraven · T. Hesselink

Wag UR Plant Breeding, Plant Science Group,

Wageningen University and Research Centre, P.O. Box

16, 6700 AA Wageningen, The Netherlands

e-mail: frans.krens@wur.nl

J. T. N. M. Thissen

Wag UR Biometris, Plant Science Group, Wageningen University and Research Centre, P.O. Box 16, 6700 AA

Wageningen, The Netherlands non- $h$ th controls were planted in a random block design in a field trial in 40 replicates. Scab resistance was monitored after artificial inoculation (first year) and after natural infection (subsequent years). After the trial period, the level of expression of the $h$ th gene was checked by quantitative RT-PCR. Four of the six GM hth apple lines proved to be significantly less susceptible to apple scab and this trait was found to be stable for the entire 4-year period. Hth expression at the mRNA level was also stable.

Keywords Apple $\cdot$ Agrobacterium-mediated transformation - Scab resistance - Field trial . Expression $\cdot$ Long-term stability

\section{Introduction}

Among the pests and diseases that waylay apple cultivation in Europe the most prominent one is apple scab, a fungal disease caused by Venturia inaequalis. Protecting the crop and ensuring sufficient production requires the extensive use of fungicides, i.e. 15-20 sprayings per season. To accommodate with the increasing desire of consumers and growers to significantly reduce the usage of chemical crop protectants there is a great need for scab-resistant apple varieties. Identification of resistance in wild apples, such as Malus floribunda 821, initiated targeted conventional breeding programmes to introduce this trait into edible 
commercial cultivars (Crandall 1926; Hough 1944). It took approximately 50 years after the first crosses before high quality, scab resistant apple cultivars, such as 'Santana' and 'Topas', could be introduced on the market in 1998. Specific characteristics of apple as a crop, i.e. its long generation period (6-8 years), its selfincompatibility preventing recurrent back-crosses with the elite parent and the linkage-drag associated with crosses with wild relatives, can be held responsible for this fact. The resistance of 'Santana' and 'Topas' is derived from the $V f$-locus of $M$. floribunda 821 (Patocchi et al. 1999; Vinatzer et al. 2001).

Unfortunately, the resistance provided by the $V f$-locus proved to be not very durable. Parisi et al. (1993) were the first to report that specific isolates of $V$. inaequalis were capable of overcoming this resistance, meaning that large-scale application of this type of resistant cultivars would render it useless within a few years (Nicholson and Rahe 2004). In order to produce really durable resistant cultivars, multiple independent resistance genes should be stacked, possibly also with non-host resistance genes if available. Achieving this by conventional breeding is virtually impossible. Genetic modification can serve as a more rapid and targeted alternative, ensuring the maintenance of the elite quality traits of the recipient cultivar.

Genetic modification protocols for apple were developed for different cultivars (James et al. 1989; Puite and Schaart 1996) and were used to introduce different genes to provide scab resistance, e.g. from micro-organisms such as Trichoderma (Bolar et al. 2000; Faize et al. 2003), from plant species such as wheat or barley (Faize et al. 2004; Janse et al. 2002) or from apple itself, such as the HcrVf2 gene (Belfanti et al. 2004; Joshi et al. 2011; Malnoy et al. 2008; Szankowski et al. 2009). In greenhouse disease assays some transgenic lines did give a significant reduction in symptom development varying from 10 (wheat puroindolin-b, Faize et al. 2004) to $100 \%$ (Trichoderma endochitinase, Bolar et al. 2000 or apple HcrVf2, Belfanti et al. 2004; Joshi et al. 2011; Szankowski et al. 2009). However, some of the resistant transgenic lines carrying the Trichoderma gene seemed to pay a growth penalty (Bolar et al. 2000; Faize et al. 2003). On the other hand, the lines carrying the puroindolin-b gene showed resistance not only to Venturia race 1 but also to race 6 which has overcome the resistance provided by the apple
HcrVf2 gene (Faize et al. 2004). This demonstrates the potential for increasing the durability of resistance introduced by genetic modification not only by stacking different apple-derived (cis-)genes (Joshi et al. 2011) but also by combining multiple genes from different origins including non-host plant genes. A prerequisite then is that such introduced resistances prove to be stable in the field under orchard conditions and over a long period of time. Recently, Borejsza-Wysocka et al. (2010) demonstrated the long-term stability of phenotype and expression of the attacin $\mathrm{E}$ gene against fire blight in transgenic apple trees in the field.

In monocots, type 1 thionins are isolated from the endosperm, e.g. from wheat (purothionins) and barley (hordothionins). Type 2 thionins are present in leaves from e.g. barley (for a review see Florack and Stiekema 1994).Thionins were found to be candidates for studying their effect on apple diseases, as these small (approx. $5 \mathrm{kDa}$ ) proteins inhibit in vitro growth of a number of fungi and bacteria (Cammue et al. 1992; Molina et al. 1993; Terras et al. 1993), including $V$. inaequalis (Mouris 1996). Transgenic tobacco carrying the barley type $1 \alpha$-hordothionin gene with CaMV35S promoter showed enhanced resistance to Pseudomonas syringae pv. tobacco and pv. syringae (Carmona et al. 1993). We introduced the barley type $1 \alpha$-hordothionin gene under regulation of an enhanced CaMV35S promoter in apple. The transgenic apple lines were made in 1996, molecularly characterized in 1997 and after transfer to soil small trees were tested in the greenhouse in 1998-1999 for apple scab incidence. A permit for a field trial was first applied for in 2000 and obtained in 2003. The trees were planted in the field in 2003 and were monitored in four successive years. In this paper we describe the performance and long-term stability in the field of transgenic apple trees equipped with the barley hordothionin gene with respect to resistance against $V$. inaequalis.

\section{Materials and methods}

Plant material and transformation

Maintenance of the shoot cultures of the apple cultivars Gala (Regal Prince) and Elstar, the transformation protocol, and the different media used were 
as reported by Puite and Schaart (1996). In experiments with Gala the shoot induction medium 3 (SIM3) was used. The thidiazuron concentration in SIM4 used for Elstar was increased to $8.8 \mathrm{mg} / \mathrm{l}$. Selection was on SIM containing $75 \mathrm{mg} / \mathrm{l} \mathrm{kanamycin}$ and $250 \mathrm{mg} / \mathrm{l}$ cefotaxim for 4 weeks; growing calli were isolated and transferred to fresh SIM and subcultured every 4 weeks, the first subculture in the continued presence of kanamycin and cefotaxim. Shoots were collected from callus and cultured on shoot elongation medium (SEM) with $250 \mathrm{mg} / \mathrm{l}$ cefotaxim.

Transformations were carried out with the A. tumefaciens strain AGL0 (Lazo et al. 1991) carrying the binary plasmid pMOG402.hth.gusintron. The coding sequence of the I-hordothionin gene $h t h$ was identical as in the gene construct $\mathrm{pC} 1 \alpha$ described by Florack et al. (1994). Expression of the hth gene was controlled by an enhanced CaMV35S promoter and a nopaline synthase (NOS) terminator. The expression cassette was cloned into the binary plasmid pMOG402, the predecessor of pMOG410 (Hood et al. 1993) carrying the selectable marker gene nptII with NOS promoter and NOS terminator and the reporter gene gusintron with CaMV35S promoter and CaMV35S terminator, yielding pMOG402.hth.gusintron (Fig. S1 in supplementary material).

Rooting and preparation for the field trial

Rooting was induced on rooting medium (Puite and Schaart 1996) supplemented with $75 \mathrm{mg} / \mathrm{l}$ kanamycin to confirm the transgenic nature of the lines that were obtained (transformation events). Further molecular analysis was done by PCR, Southern and northern blotting (data not shown). For entering the field trial only lines, free of backbone sequences from the binary plasmid, could be used. The rooted plants were transferred to the greenhouse. As a control nontransformed in vitro propagated plants and plants transformed with AGL0 (pMOG410), carrying only the nptII and gusintron genes, were taken and transferred to the greenhouse. In addition, in vitro propagated plants of cultivar Santana, carrying the natural $V f$ gene coding for resistance to Venturia inaequalis, were included. For a high survival rate of the rooted in vitro plantlets a continuous adaptation of the humidity conditions was required. The rooted plants were planted in pots with sterilized soil and placed in a covered tray in the greenhouse $\left(20^{\circ} \mathrm{C}\right)$ at $100 \%$ relative humidity. The cover was removed gradually in the next weeks. After 4 weeks the plants were potted in larger pots and transferred to a conditioned greenhouse at $18 / 13^{\circ} \mathrm{C}$.

Based on preliminary greenhouse apple scab disease assays (data not shown), the six most promising $h t h$ lines and all controls were grafted on rootstock MM106 after one growing season in the greenhouse. The plants, 10-15 individuals per line, were then potted. After 1 year of growth in a nonconditioned greenhouse, a second round of grafting was done in winter on MM106 using dormant axillary buds as scions. 50 Individuals per lines were prepared of which 40 were used for planting in the field; the rest served as backup.

\section{Field trial setup}

The field trial consisted of a total of 420 trees, planted in four rows of 105 individual trees running from North to South. Twenty of them, individuals of $\mathrm{cv}$. 'Red Elstar' grafted on rootstock M9, $3 \times 4$ at the north end and $2 \times 4$ at the south end, were planted to prevent any border effects there. Those were not included in further screenings. The remaining 400 represented 40 replicates of 10 lines; 5 individual transgenic 'Gala' lines carrying the hth gene, 1 transgenic 'Elstar' line with hth, 1 transgenic 'Gala' control without the $h t h$ gene, an untransformed 'Elstar' control, an untransformed 'Gala' control and cv. 'Santana' as a scab resistant control. All apple trees were planted in October 2003 in a randomized block design with 10 trees of each line randomized in each row, supported by wooden poles, within the row at a distance of $1.75 \mathrm{~m}$; the distance between the rows was $3.5 \mathrm{~m}$. During the entire trial period normal apple cultivation practice was performed with respect to trimming, weed control, insect control and controlling mildew; flower clusters were physically removed by hand before flowers could open as required by law. No spraying against apple scab was done. The plot was surrounded by a fence to prevent larger mammals, such as hares and roes to enter.

Scab resistance assay

The aim of the trial was to mimic as much as possible the natural situation in an orchard in The Netherlands. 
For this we had a preference for a natural infection process. However, to ensure that spores of $V$. inaequalis, the fungal pathogen, would be present in the plot to allow natural development of the disease, a spore suspension was sprayed on the top five leaves of each tree in September 2004. The suspension consisted of an inoculum of $5 \times 10^{5}$ spores $/ \mathrm{ml}$; a mixture of $V$. inaequalis conidia had been isolated from sporulating lesions from susceptible seedlings from the Wageningen UR apple breeding location at Randwijk, The Netherlands. The composition of the mixture with respect to the isolates being present was not characterized prior to use but earlier observations had established that the mixture did not contain the isolates 6 and 7 , virulent on the $V f$ containing resistant cv. 'Santana'. Spraying was done until the leaves were wet. During this inoculation it was found that already natural infection had taken place by a $V$. inaequalis isolate that was not further characterized. Scoring of the disease symptoms in 2004 was done 9 and 30 days after inoculation on the inoculated top five leaves using the grading scale as described by Parisi et al. (1993) based on the percentage of leaf area with sporulating symptoms. In subsequent years no further artificial inoculations were done; disease scoring was performed in summer or autumn as soon as substantial damage and symptoms were observed on the non-transgenic controls. The method that was used for scoring the disease was based on the semiquantitative classification Vi-F-2 as described by King et al. (1998) for field evaluations of scab incidence. Scoring and the attribution of scale values were not based on observations of single, isolated leaves per tree but on the overall picture provided by multiple leaves, preferably on multiple branches showing symptoms. The scales are 0 for no scab, $0 \%$ leaves attacked; 1 for some sporulating leaves or a number of leaves together with occasional specks, 1-10\% leaves attacked; 2 for multiple branches with moderate sporulations on leaves, $11-35 \%$ leaves attacked; 3 for moderate symptoms on approximately half of the leaves or heavier infestations on somewhat less, 36-65\% leaves attacked; 4 for approximately two-thirds of the leaves showing serious infestation, 66-90\% leaves attacked and 5 for almost all leaves heavily affected or even dropped off, 91-100\% leaves attacked. Two persons were involved in the evaluation of symptom development and worked independently. For year 2007, the two data sets were used separately in statistical analysis to see whether they would lead to differences in the outcome. One person scored 1 month earlier than the other.

\section{Statistical analysis}

With the data of the first year a non parametric $\left(\chi^{2}\right)$ test was compared to an analysis of variance showing no difference in the outcome due to the large number $(n=40)$ of replicates. Further analysis of the scab resistance scores was done with an analysis of variance each year. Also an overall analysis of variance over the years was performed taking year as blocking factor. With year as blocking factor the slightly different scoring scales (according to Parisi et al. (1993) in year 2004 and King et al. (1998) in subsequent years) do not have any consequences for the tests of the line effects. This last analysis was carried out on the means of the lines per year.

\section{Quantitative real-time PCR}

Young, completely unfolded leaves were harvested from three individual trees per line in the spring of 2008 for seven of the lines. The three individuals were selected based on consistency of scoring throughout the 4-year period at or close to the aggregated value from all 40 individuals (see Table 3). For line 6, three individuals were chosen that had given the lowest incidence data throughout the years as well as three that had shown the highest incidence data. Directly after harvest in the field the leaves in duplicate samples were put on ice and transported to the lab where they were frozen in liquid nitrogen and stored at $-80^{\circ} \mathrm{C}$. One sample of the leaves was used for protein extraction (see ELISA) and the other for isolation of total RNA using the method as described by Asif et al. (2000). The RNA samples were run on a $1 \%(\mathrm{w} / \mathrm{v})$ agarose gel to determine the RNA quality. An aliquot total RNA of $2 \mu \mathrm{g}$ was used to treat with DNaseI (Invitrogen Carlsbad, CA, USA) and it was subsequently reverse transcribed with a blend of oligo (dT) and random primers to synthesis cDNA using iScript first strand cDNA synthesis kit (Bio-rad Hercules, CA, USA). The reactions were performed according to the manufacturers guidelines.

The qRT-PCR was performed with iQ $\mathrm{SYBR}^{\circledR}$ green super mix (Bio-rad) with MyiQ Single Color 
Real time detection system. As endogenous reference the $\beta$-actin gene (Accession number DT002474) was used. The primer sequences used for qRT-PCR are presented in Table 1. All the PCR reactions were carried out in duplicates. Hth gene expression levels were analyzed by using relative quantification method i.e. $2^{-\Delta \Delta \mathrm{Ct}}$ method through qRT-PCR (Li et al. 2004). The threshold cycle (Ct) is the PCR cycle at which a statistically significant increase in the transcript is first detected.

The normalized $\mathrm{Ct}$ value difference $(\Delta \mathrm{Ct})$ was calculated from $\mathrm{Ct}(h$ th) $-\mathrm{Ct}$ ( $\beta$-actin) for all the reactions. The $\Delta \mathrm{Ct}$ value of one randomly chosen transgenic individual carrying the $h t h$ gene as reference sample and, for all samples, relative $\Delta \Delta \mathrm{Ct}$ values were calculated using $\Delta \mathrm{Ct}$ (reference sample)$\Delta \mathrm{Ct}$ (target sample). Finally, the transgene expression levels were determined as fold change using the formula $2^{-\Delta \Delta \mathrm{Ct}}$.

\section{ELISA}

Leaf samples were prepared for protein extraction by puncturing the leaves four times with the lid of an Eppendorf tube. The tubes with the round leaf parts within were directly frozen in liquid nitrogen. The plant material was ground inside the tube and suspended in $200 \mu \mathrm{l}$ extraction buffer (EB) consisting generally of $1 \times$ phosphate buffered saline (PBS), $5 \mathrm{mM}$ EDTA and $0.05 \%(\mathrm{v} / \mathrm{v})$ Tween 20 . The samples were vortexed and kept on ice. When all samples were ready, the tubes were centrifuged in an Eppendorf centrifuge and the supernatants were transferred to fresh tubes and were used in the ELISA after measuring the protein quantities by the method of Bradford (1976). As an alternative, the extraction was done by grinding leaf material in $\mathrm{H}_{2} \mathrm{SO}_{4}$, followed by TCA precipitation, freeze-drying the precipitate and subsequently dissolving it in $1 \%(\mathrm{v} / \mathrm{v})$ acetic acid as described earlier (Florack et al. 1994).

ELISAs were done as follows. A polyclonal antiserum raised in rabbit against hordothionin, coupled to bovine serum albumin (BSA) was used in the primary reaction followed by exposure to a goat anti-rabbit antibody linked to alkaline-phosphatase (AP) from Sigma. Signal detection was by 4-nitrophenyl phosphate disodium hexahydrate. The ELISAs were read at $415 \mathrm{~nm}$ in a spectrophotometer (ELx808, BioTek Instruments, Inc.). The background was reduced as much as possible by choosing the optimal extraction buffer (see above) and by blocking with $1 \%$ (w/v) PerfectBlock from MoBiTec (\# PB01), $0.2 \%(\mathrm{v} / \mathrm{v})$ Tween 20 in $1 \times$ PBS. A calibration curve was prepared with eight 1:1 dilutions starting with $100 \mathrm{ng}$ of purified hordothionin from barley in $1 \times$ PBS or in $1 \times$ PBS with extract of the negative apple control (20:1).

\section{Results}

Production of transgenic, hth-containing apple lines

Two transformation experiments yielded 2 transgenic 'Elstar' lines and 32 transgenic 'Gala' lines as demonstrated by PCR analysis (data not shown). All lines, including controls, such as non-transformed susceptible 'Elstar' and 'Gala', a transformed 'Gala' (with nptII and gus, but without $h t h$ ) and non-transformed resistant 'Santana', were rooted and taken to the greenhouse to run preliminary scab assays, firstly on their own roots, secondly in more replicates after grafting axillary buds on rootstock MM106. Based on the results of the greenhouse scab assays (data not shown), a selection was made of transgenic lines

Table 1 Primer sequences used in qRT-PCR

\begin{tabular}{lllr}
\hline Primer & Gene bank accession & Sequence & Fragment length (bp) \\
\hline Hth & & & 72 \\
Forward & X05901 & 5'-ATTGCAACTTGGGGTGTAGG-3' $^{\prime}$ & \\
Reverse & & 5'-CATTTCTTCGTCGTCAGCAG-3' $^{\prime}$ & 82 \\
MdActin & & & \\
Forward & DT002474 & 5'-CTATGTTCCCTGGTATTGCAGACC-3' $^{\prime}$ & \\
Reverse & & 5'-GCCACAACCTTGTTTTCATGC-3' \\
\hline
\end{tabular}


giving a significant reduction in symptom development at a $P<0.005$ level in a Student's $t$-test. The selection consisted of 2 'Elstar' lines and 5 'Gala' lines, which was further characterized by Southern and northern blot analysis. All lines contained 2-3 T-DNA inserts except for one 'Elstar' line, which had 6-7 copies, and all showed expression of the hth gene (data not shown). Eventually, 1 'Elstar' line and 5 'Gala' lines were prepared to enter the field trial together with the controls (see Table 2); the 1 'Elstar' line with the many T-DNA copies (E04) was left out because it proved to contain backbone sequences of the binary vector including the bacterial antibiotic resistance gene $n p t I I I$.

Southern analysis also indicated that line G-56 and G-60 were clones, i.e. coming from the same transformation event, possibly due to a mistake during in vitro propagation. Because those two lines had been handled separately in greenhouse testing, grafting and preparation for the field trial, this information was not shared with the people monitoring in the field in order to have an extra control on reliability of the scoring.

Scab resistance in the field

One year after planting, in September 2004, the upper five and therefore, the youngest leaves of all 420 trees were manually infected with $V$. inaequalis spores; some trees already showed signs of a natural infestation. Scoring for disease was done after 10 and 30 days and yielded the first data set on resistance with a ranking of the lines as given in Table 2. In subsequent years, the fungus was not introduced artificially any more; scab disease developed naturally and scoring was done whenever clear symptoms were visible on the non-transgenic, susceptible controls. Because of variations in environmental and climatal conditions from 1 year to the next, the moments of scoring varied, i.e. in July in 2005, in August in 2006 and in August/September in 2007. The means of the individual years and the aggregated data for the entire period of 4 years are presented in Table 2. Figure 1 shows the appearance of some exemplary trees from the best performing transgenic line and a non-transgenic control at the moment of scoring in 2005. Cv. 'Santana' was not included in the statistical analysis because it did not show any symptoms at all during the entire field trial and the value zero could not be handled by the statistical instruments used. Although there was some variability in ranking comparing individual years, the overall picture was that over the entire period of 4 years significant differences existed between the lines. Four of the six transgenic lines showed a significant reduction in symptom development, two transgenic lines did not prove to be different from the controls. The percentage of scab incidence compared to the controls ranged from 36.4 to $65 \%$ for the four lines (Table 2).

Table 2 List of apple lines incorporated in the field trial and means of the scab disease scores for the individual 4 years and of all data combined

\begin{tabular}{|c|c|c|c|c|c|c|}
\hline Line & 2004 & 2005 & 2006 & 2007 & $2004-2007(\mathrm{SD}=0.592)$ & $\%$-Age scab disease scores \\
\hline G-60 (hth+) & 1.325 (a) & 2.275 (a) & 0.750 (a) & 0.912 (a) & 1.169 (a) & 36.4 \\
\hline G-56 (hth+) & 1.750 (a) & 1.897 (a) & 0.850 (a) & 0.800 (a) & 1.187 (a) & 37.0 \\
\hline G-68 (hth+) & $2.750(\mathrm{~b})$ & 2.154 (a) & 1.158 (a) & $1.381(\mathrm{~b})$ & $1.647(\mathrm{ab})$ & 51.3 \\
\hline G-15 (hth+) & $2.077(\mathrm{ab})$ & $3.667(\mathrm{~cd})$ & $1.900(b)$ & $1.437(b)$ & $2.086(\mathrm{bc})$ & 65.0 \\
\hline G-65 (hth+) & $4.000(\mathrm{c})$ & $4.075(\mathrm{de})$ & $2.300(\mathrm{bc})$ & 1.461 (b) & $2.754(\mathrm{~cd})$ & 85.8 \\
\hline E-Co (hth-) & $4.925(\mathrm{de})$ & 3.359 (c) & 1.950 (b) & $2.800(\mathrm{~d})$ & 2.977 (d) & 100 \\
\hline G-GMCo (hth-) & $4.100(\mathrm{~cd})$ & $4.200(\mathrm{ef})$ & $2.725(\mathrm{c})$ & $1.987(\mathrm{c})$ & $3.044(d)$ & 100 \\
\hline E-06 (hth+) & $5.200(\mathrm{e})$ & $2.700(\mathrm{~b})$ & $2.400(\mathrm{bc})$ & $3.317(\mathrm{~d})$ & $3.094(d)$ & 104 \\
\hline G-Co (hth-) & 4.400 (cde) & 4.525 (f) & $2.675(\mathrm{c})$ & $2.762(\mathrm{~d})$ & $3.375(d)$ & 100 \\
\hline Santana $^{\mathrm{a}}$ & - & - & - & - & & \\
\hline
\end{tabular}

Scoring was done essentially according to the scaling of Parisi et al. (1993; year 2004) and to the descriptor Vi-F-2 as described by King et al. (1998; years 2005, 2006 and 2007). The different ranking letters between brackets refer to significant differences at the $P=0.05$ level in an analysis of variance. The percentage of scab disease scores was calculated relative to the respective controls

a Santana did not show any symptoms and scored consistently a value of 0 


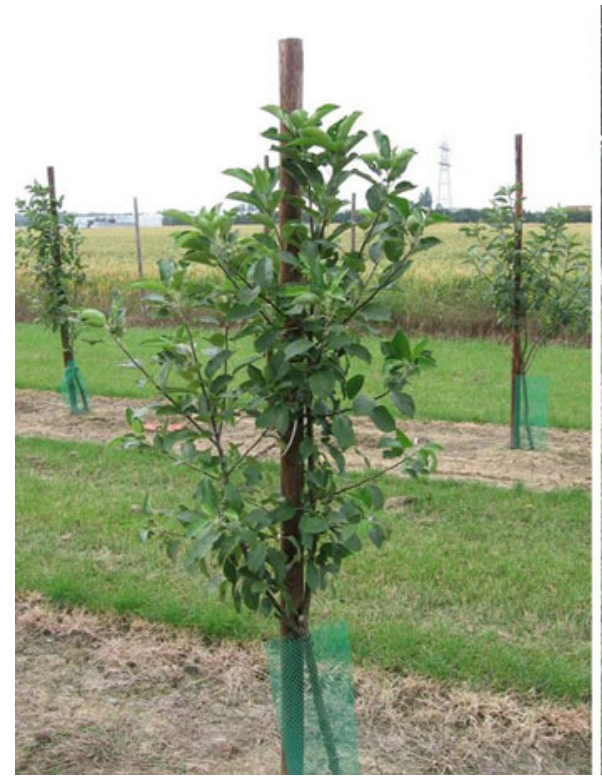

Fig. 1 Growth habitus in July 15th, 2005, a year with severe scab infestation levels all around The Netherlands. Left: a representative of the best performing transgenic, hth containing

Incorporating the datasets of 2007 of the two evaluators separately in the statistical analysis did not lead to any significant differences in the ranking; incidence levels were somewhat higher at the later moment of scoring. In Table 2 the mean of the two sets is given in the column for 2007. For the aggregated data the outcome was identical.

Phenotypically, the transgenic lines did not show any aberrations with one exception. Within the 40 individuals of lines G-56 and G-60, approximately half showed leaves that looked more dark green and had a more pointy tip than the other 'Gala' lines, transgenic or not. The clonal lines G-56 and G-60 also proved to behave identical in the field trial throughout the years for scab resistance, demonstrating the reliability of the disease testing and scoring. They were consistently the best performing ones.

\section{Hth gene expression}

Northern analysis had shown transcription of mRNA from the introduced $h t h$ gene in all transgenic lines (data not shown). In 2008, 12 years after the transformation experiments, young leaves were isolated in the field and used for qRT-PCR screening on cDNA prepared from total RNA. Lines G-60 and G-65 were

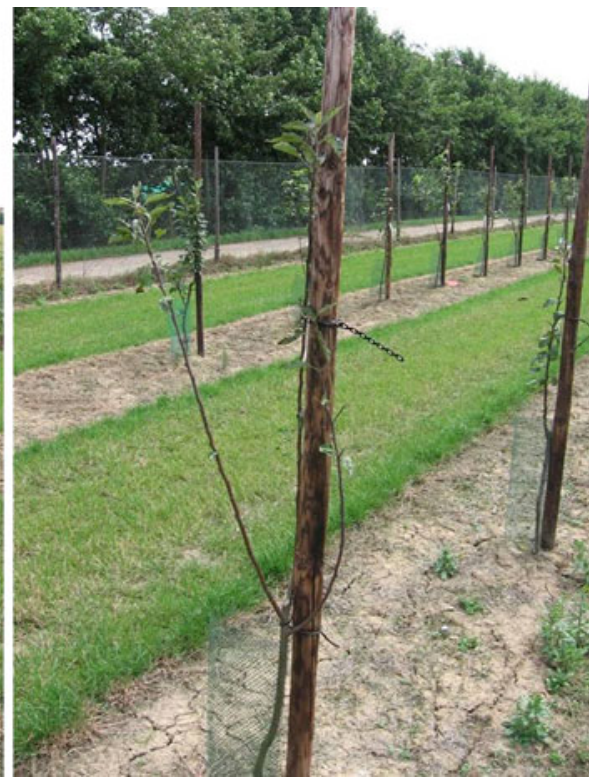

'Gala' apple line, G-60; right: a representative of the non-GM 'Gala' control, G-Co (hth-), defoliated by scab

not included in this analysis, however from line G-56 from the original 40 replicates three individuals were taken showing consistently the highest resistance and three showing consistently the lowest in order to see whether this would translate into different expression levels. The data, given in Table 3, showed that in the control lines without the hth gene no expression was found. Only in lines carrying the hth gene, expression was demonstrated meaning that the gene was still actively transcribed after 12 years. The levels of expression could not be correlated to the level of resistance when the lines were compared as shown in Fig. 2. Indeed, within line G-56 where six individuals were investigated, consisting of the three best performing trees and the three worst performing trees, five showed comparable expression levels.

HTH protein level determination by ELISA

First, the protein extraction protocol was optimized by varying detergents, Tween 20 or Triton $X-100$, and detergent concentrations in the basic solution of $1 \times$ PBS/5 mM EDTA. The conditions giving best protein extraction combined with the least background in the ELISA proved to be $1 \times \mathrm{PBS} / 5 \mathrm{mM}$ EDTA/0.05\% $(\mathrm{v} / \mathrm{v})$ Tween20. Both in the absence as well as in the 
Table 3 Relative expression of the $h t h$ gene as determined by quantitative RT-PCR

\begin{tabular}{lll}
\hline Apple line & $\begin{array}{l}\text { Relative } h t h \\
\text { expression }\end{array}$ & $\begin{array}{l}\text { Significant difference } \\
(P=0.05)\end{array}$ \\
\hline G-Co (hth-) & 0.0000 & \\
E-Co (hth-) & 0.0000 & \\
G-GMCo (hth-) & 0.0000 & \\
G-56 & 0.5867 & $\mathrm{a}$ \\
G-15 & 0.6000 & $\mathrm{a}$ \\
E-06 & 0.8467 & $\mathrm{ab}$ \\
G-68 & 1.0033 & $\mathrm{~b}$ \\
\hline
\end{tabular}

The values represent the mean relative expression of three individual trees sampled per line (for line G-56 six individuals were measured). Different letters in the last column point at significant differences between the lines at the $P=0.05$ level $(\mathrm{SD}=0.18)$

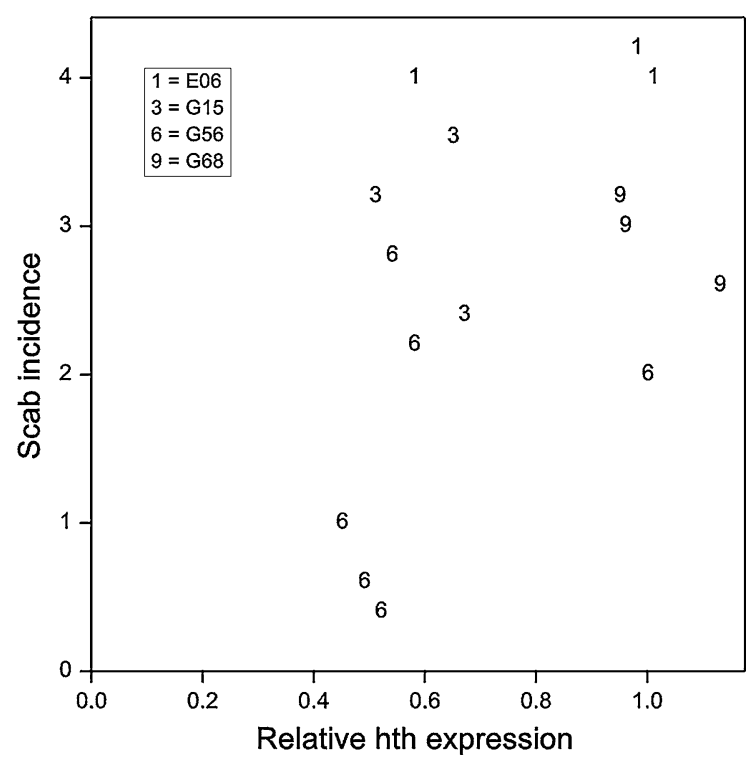

Fig. 2 The mean scores (over years) with respect to scab incidence for 15 individual trees are plotted against their relative $h t h$ expression

presence of apple extract (the non-GM control 'Gala' was used for this) a good calibration curve was obtained with a detection limit between 1 and $10 \mathrm{ng}$ HTH. Unfortunately, no HTH could be detected in any of the samples including those from plants carrying the $h t h$ gene and expressing it. It is known that HTH can be compartmentalized (Florack and Stiekema 1994), which might hamper easy extraction by conventional protocols. Therefore as an alternative, the extraction method was followed as described by Florack et al. (1994) based on sulfuric acid and proven successful in tomato, potato and tobacco. However, protein quantity determinations failed to show any protein whatsoever in the extracts that were produced in this way, so this approach was discontinued. No HTH protein data could be obtained from our apple trees.

\section{Discussion}

From several independent transformation experiments exposing approximately 1,500 explants per cultivar to Agrobacterium multiple independent transformed lines were isolated. Great differences per cultivar were observed. For cv. 'Elstar' ultimately, two transgenic lines carrying the $h$ th gene as confirmed by PCR analysis were isolated; for cv. 'Gala' 32 transgenic lines. Recently, higher transformation efficiencies have been routinely obtained (Joshi et al. 2011) but the differences per cultivar remained. Further characterization of the transgenic lines, molecularly by Southern and northern blotting and by greenhouse disease assays, resulted in a selection of one transgenic 'Elstar' line and five transgenic 'Gala' lines to be incorporated in the field trial. Here, we have shown that good performance of the selected lines in the greenhouse scab assays was no guarantee for good performance under orchard field conditions. None of the 'Elstar' hth GM lines proved to give satisfactory resistance against scab and would be selected for further experimentation or commercialization. Starting from 32 GM 'Gala' lines, four gave a significantly higher level of resistance against scab of which two were demonstrated to be clones. Apple growers indicated that $65 \%$ less symptoms would be commercially interesting for cultivation (Van der Linden, Inova Fruit b.v., The Netherlands, pers. commun.). Indeed, only one line, G-56/G-60, met this requirement. This demonstrated that sufficiently large numbers of primary transformed lines need to be produced to eventually end up with some commercially interesting ones. In addition to resistance levels the long-term stability is important for apple as a crop. Looking at performance on scab resistance in the field over a period of multiple years showed that the trait as a result of a transformation event with the barley hordothionin gene was stable. Although some minor 
changes could be observed in ranking of the individual lines from 1 year to another, the overall picture was clear with significant differences between the lines after aggregating the data of all 4 years.

It should be noted that the best performing line was the scab resistant cultivar 'Santana'. 'Santana' was produced by conventional breeding and contains the $V f$-resistance locus derived from Malus floribunda 821 (Patocchi et al. 1999; Vinatzer et al. 2001). 'Santana' did not show any symptoms during the entire trial period. The HcrVf2 gene present within the $V f$-gene cluster and solely responsible for the resistant phenotype (Joshi et al. 2011) apparently worked much better against apple scab than the hthgene from barley. For this reason and for reasons of potentially better consumer acceptance this and other apple-derived scab resistance genes were isolated and used in apple improvement by genetic modification (Belfanti et al. 2004; Joshi et al. 2011; Malnoy et al. 2008; Szankowski et al. 2009). However, the resistance provided by the HcrVf2 gene was already broken (Parisi et al. 1993) by new virulent isolates of the fungus $V$. inaequalis. To cope with this problem it is necessary to combine multiple resistance genes preferably responsible for different defense mechanisms. Resistance genes derived from apple or wild relatives can be used in gene pyramiding, but also non-host resistance genes obtained from other plant species, such as the wheat puroindolin-b gene (Faize et al. 2004) or the hordothionin gene of barley as presented here, might play an important role in raising the barriers to pathogen attack. Such combinations cannot be achieved by conventional breeding but only by genetic modification. Gene pyramiding requires either transformations with vectors carrying different combinations or retransformations of already transformed lines adding new genes to the ones introduced earlier. For the latter, a marker-free (MF) system is required where selectable marker genes are removed after use and the MF transgenic lines can be used in a second round of gene transfer using the same selection system that was optimized for the crop (Schaart et al. 2004; Krens et al. 2004). This approach is currently being investigated in our group.

Not only the resistance trait was found to be stable, also transcription into mRNA from the $h t h$ gene was stable over $>10$ years. Northerns done in 1998 showed active transcription in the GM lines and quantitative RT-PCR done on mRNA isolated from leaves harvested in 2008 indicated that expression of the hth gene was still present. It was clear that only when the hth gene was present the transcript was found. The levels of mRNA production could not be correlated to the observed resistance levels of the individual lines. Posttranscriptional regulatory processes could be responsible for that. Unfortunately, the presence of the hordothionin protein $(\mathrm{HTH})$ could not be established by ELISA, qualitatively nor quantitatively. This could be due to the fact that protein levels were below the detection limit of $1 \mathrm{ng}$ or by inadequate extraction methods. Hordothionin is known to be compartmentalized (Florack and Stiekema 1994) and this could have blocked efficient release of HTH protein. In tobacco plants carrying the $h t h$-transgene, hordothionin was present in the "microsomal" and "membrane" fractions, and was not secreted in the apoplast (Florack and Stiekema 1994). In analogy, thionins produced by the hthtransgenic apple plants could accumulate intracellularly, most likely in the cell wall (Bohlmann et al. 1988). Also in other studies correlations between mRNA and protein levels or between mRNA levels and phenotype could not be unequivocally established. In cucumber, transgenic lines carrying a dehydrin (Dhn10) gene, showed the expected phenotype, chilling tolerance, at different levels; RT-PCR confirmed expression but no protein was detected by the alkaline-phosphatase-conjugated antibody (Yin et al. 2004) and no correlation was found between mRNA levels and phenotype. In tomato after introduction of the nematode resistance gene $M i-1.2$, no correlation was found between transcript levels and resistance levels (Goggin et al. 2004) in the T3 generation. In transgenic apple lines equipped with the antibacterial attE gene derived from the cecropia moth, Borejsza-Wysocka et al. (2010) found stable expression and phenotype over a 12-year period in the orchard. They could demonstrate the presence of attacin E protein both in 2000 and 2006 and consistently reduced levels of fire blight (Erwinia amylovora) susceptibility, however, no correlation between protein level and susceptibility.

In their study, no effects on tree or fruit morphology or on fruit characteristics were found. In our study, we found some aberrations in leaf morphology in the two 
clonal lines, G-56 and G-60, i.e. more dark green and more pointy. Not all individuals of G-56 and G-60 showed this phenotype and some isolated individuals from other G-lines also showed it. Lines G-56 and G-60 proved to be the best performing with respect to resistance and this could partly be due to the change in leaf morphology. In apple, ontogenic resistance occurs against apple scab, meaning that only young leaves are susceptible and older leaves with a changed cell wall composition are resistant (Gessler and Stumm 1984; Schwabe 1979). Unfortunately, thorough growth characterizations were not possible within this trial to confirm or determine the extent of a contribution of ontogenic resistance to the performance of the lines G-56/G-60. The changes in leaf morphology in lines G-56/G-60 could have rendered them less susceptible and together with the effect of the hordothionin could have resulted in their higher level of performance. This phenotypical aberration became more prominent towards the end of the field trial.

This is the first report on long-term performance of transgenic apple trees in a field trial in Europe showing stable expression of a transgene and increased resistance to apple scab.

\section{Conclusion}

The introduction of the barley hth gene resulted in apple trees less susceptible to apple scab; controls including GM controls never showed this effect. The $h t h$ gene was stably present, transcribed and active for a period of $>4$ years in the field. No HTH protein could be detected and no correlation could be established between transcription level and resistance level.

Nevertheless, the effect on symptom reduction by the introduction of the $h t h$ gene was clear and lasting.

Acknowledgments This research was partly done within the EU-ISAFRUIT project, funded by the European Commission under the Thematic Priority 5-Food Quality and Safety of the 6th Framework Programme of RTD (contract no. FP6-FOODCT-2006-016279)

Open Access This article is distributed under the terms of the Creative Commons Attribution Noncommercial License which permits any noncommercial use, distribution, and reproduction in any medium, provided the original author(s) and source are credited.

\section{References}

Asif MH, Dhawan P, Nath P (2000) A simple procedure for the isolation of high quality RNA from ripening banana fruit. Plant Mol Biol Rep 18:109-115

Belfanti E, Silfverberg-Dilworth E, Tartarini S, Patocchi A, Barbieri M, Zhu J, Vinatzer BA, Gianfranceschi L, Gessler C, Sansavini S (2004) The HcrVf2 gene from a wild apple confers scab resistance to a transgenic cultivated variety. Proc Natl Acad Sci USA 101:886-890

Bohlmann H, Clausen S, Behnke S, Giese H, Hiller C, Reimann-Philipp U, Schrader G, Bartholt V, Apel K (1988) Leaf-specific thionins of barley-a novel class of cell wall proteins toxic to plant pathogenic fungi and possibly involved in the defence mechanism of plants. EMBO J 7:1559-1565

Bolar JP, Norelli JL, Wong KW, Hayes Ck, Harman GE, Aldwinckle HS (2000) Expression of endochitinase from Trichoderma harzianum in transgenic apple increases resistance to apple scab and reduces vigor. Phytopathology 90:72-77

Borejsza-Wysocka E, Norelli JL, Aldwinckle HS, Malnoy M (2010) Stable expression and phenotypic impact of attacin $E$ transgene in orchard grown apple trees over a 12 year period. BMC Biotechnol 10:41

Bradford MM (1976) A rapid and sensitive method for the quantitation of microgram quantities of protein utilizing the principle of protein-dye binding. Anal Biochem 72:248-254

Cammue BPA, de Bolle MFC, Terras FRG, Proost P, van Damme J, Rees SB, Vanderleyden J, Broekaert WF (1992) Isolation and characterization of a novel class of plant antimicrobial peptides from Mirabilis jalapa L. seeds. J Biol Chem 267:2228-2233

Carmona MJ, Molina A, Fernández JA, López-Fando JJ, García-Olmedo F (1993) Expression of the I-thionin gene from barley in tobacco confers enhanced resistance to bacterial pathogens. Plant J 3:457-462

Crandall CS (1926) Apple breeding at the University of Illinois. Ill Agric Exp Stn Bull 275:337-600

Faize M, Malnoy M, Dupuis F, Chevalier M, Parisi L, Chevreau E (2003) Chitinases of Trichoderma atroviride induce scab resistance and some metabolic changes in two cultivars of apple. Phytopathology 93:1496-1504

Faize M, Sourice S, Dupuis F, Parisi L, Gautier MF, Chevreau E (2004) Expression of wheat puroindoline-b reduces scab susceptibility in transgenic apple (Malus $x$ domestica Borkh.). Plant Sci 167:347-354

Florack DEA, Stiekema W (1994) Thionins: properties, possible biological roles and mechanism of action. Plant Mol Biol 26:25-37

Florack DEA, Dirkse WG, Visser B, Heidekamp F, Stiekema WJ (1994) Expression of biologically active hordothionins in tobacco. Effects of pre- and pro-sequences at the amino and carboxyl termini of the hordothionin precursor on mature protein expression and sorting. Plant Mol Biol 24:83-96

Gessler C, Stumm D (1984) Infection and stroma formation by Venturia inaequalis on apple leaves with different degrees of susceptibility to scab. J Phytopathol 110:119-126 
Goggin FL, Shah G, Williamson VM, Ullman DE (2004) Instability of $\mathrm{Mi}$-mediated nematode resistance in transgenic tomato plants. Mol Breed 13:357-364

Hood EE, Gelvin SB, Melchers LS, Hoekema A (1993) New Agrobacterium helper plasmids for gene transfer to plants. Transgenic Res 2:208-218

Hough LF (1944) A survey of the scab resistance of the foliage on seedling in selected apple progenies. Am Soc Hortic Sci 44:260-272

James DJ, Passey AJ, Barbara DJ, Bevan M (1989) Genetic transformation of apple (Malus pumilla Mill.) using a disarmed Ti-binary vector. Plant Cell Rep 7:658-661

Janse J, Schaart JG, Puite KJ, Florack DEA, Groenwold R, Pelgrom K, Krens FA (2002) Enhanced resistance against Venturia inaequalis in transgenic apple by a gene coding for hordothionin. In: 10th IAPTC\&B congress, plant biotechnology and beyond, Orlando, FL, P1019

Joshi SG, Schaart JG, Groenwold R, Jacobsen E, Schouten HJ, Krens FA (2011) Functional analysis and expression profiling of HcrVfl and HcrVf2 for development scab resistant cisgenic and intragenic apples. Plant Mol Biol (submitted for publication)

King GJ, Alston FH, Brown LM, Chevreau E, Evans KM, Dunemann F, Janse J, Laurens F, Lynn JR, Maliepaard C, Manganaris AG, Roche P, Schmidt H, Tartarini S, Verhaegh J, Vrieling R (1998) Multiple field and glasshouse assessments increase the reliability of linkage mapping of the $V f$ source of scab resistance in apple. Theor Appl Genet 96:699-708

Krens FA, Pelgrom KTB, Schaart JG, den Nijs APM, Rouwendal GJA (2004) Clean vector technology for markerfree transgenic fruit crops. Acta Hortic 663:431-436

Lazo GR, Stein PA, Ludwig RA (1991) A DNA transformation-competent Arabidopsis genomic library in Agrobacterium. Bio/Technology 9:963-967

Li Z, Hansen JL, Liu Y, Zemetra RS, Berger PH (2004) Using real-time PCR to determine copy number in wheat. Plant Mol Biol Rep 22:179-188

Malnoy M, Xu ML, Borejsza-Wysocka E, Korban SS, Aldwinckle HS (2008) Two receptor-like genes, Vfal and $V f a 2$, confer resistance to the fungal pathogen Venturia inaequalis inciting apple scab disease. Mol Plant Microbe Interact 21:448-458

Molina A, Goy PA, Fraile A, Sanchez-Monge R, Garcia-Olmedo $F$ (1993) Inhibition of bacterial and fungal plant pathogens by thionins of types I and II. Plant Sci 92:169-177

Mouris J (1996) Antifungal activity of a number of antimicrobial peptides. CPRO-DLO report, Wageningen
Nicholson RL, Rahe JE (2004) Apple scab and its management. In: Mukerji KG (ed) Fruit and vegetable diseases. Kluwer, Dordrecht, pp 41-58

Parisi L, Lespinasse Y, Guillaumès J, Kruger J (1993) A new race of Venturia inaequalis virulent to apples with resistance due to the $V f$ gene. Phytopathology 83:533-537

Patocchi A, Vinatzer BA, Gianfranceschi L, Tartarini S, Zhang H-B, Sansavini S, Gessler C (1999) Construction of a $550 \mathrm{~kb}$ BAC contig spanning the genomic region containing the apple scab resistance gene $V f$. Mol Gen Genet 262:884-891

Puite KJ, Schaart JG (1996) Genetic modification of the commercial apple cultivars Gala, Golden Delicious and Elstar via an Agrobacterium-mediated transformation method. Plant Sci 119:125-133

Schaart JG, Krens FA, Pelgrom KTB, Mendes O, Rouwendal GJA (2004) Effective production of marker-free transgenic strawberry plants using inducible site-specific recombination and a bifunctional selectable marker gene. Plant Biotechnol J 2:233-240

Schwabe WFS (1979) Changes in the scab susceptibility of apple leaves as influenced by age. Phytophylactica 11:53-56

Szankowski I, Waidman S, Degenhardt J, Patocchi A, Paris R, Silfverberg-Dilworth E, Broggini G, Gessler C (2009) Highly scab-resistant transgenic apple lines achieved by introgression of $\mathrm{HcrVf} 2$ controlled by different native promoter lengths. Tree Genet Genomes 5:349-358

Terras FRG, Schoofs HME, Thevissen K, Osborn RW, Vanderleyden J, Cammue BPA, Broekaert WF (1993) Synergistic enhancement of the antifungal activity of wheat and barley thionins by radish and oilseed rape $2 \mathrm{~S}$ albumins and by barley trypsin inhibitors. Plant Physiol 103:1311-1319

Vinatzer BA, Patocchi A, Gianfranceschi L, Tartarini S, Zhang H-B, Gessler C, Sansavini S (2001) Apple contains receptor-like genes homologous to the Cladosporium fulvum resistance gene family of tomato with a cluster of genes cosegregating with $V f$ apple scab resistance. Mol Plant Microbe Interact 14:508-515

Yin Z, Pawlowicz I, Bartoszewski G, Malinowski R, Malepszy S, Rorat T (2004) Transcriptional expression of a Solanum sogarandinum pGT:Dhn10 gene fusion in cucumber, and its correlation with chilling tolerance in transgenic seedlings. Cell Mol Biol Lett 9:891-902 